\title{
ANALISIS PENGARUH KINERJA PERUSAHAAN TERHADAP PENGUNGKAPAN ISR BANK UMUM SYARIAH TAHUN 2010-20141)
}

\author{
Nia Fajriyatun Nadlifiyah \\ Mahasiswa Program Studi S1 Ekonomi Islam-Fakultas Ekonomi dan Bisnis-Universitas Airlangga \\ Email : nia.fajriyatun-12@feb.unair.ac.id
}

Nisful Laila

Departemen Ekonomi Syariah- Fakultas Ekonomi dan Bisnis-Universitas Airlangga

Email : nisful.laila@feb.unair.ac.id

\begin{abstract}
:
The Effect of Corporate Performance Toward of ISR Disclosure for Shariah Commercial Bank (BUS) in Indonesia During 2010-2014. This research aims to find out the effect of corporate performance toward of ISR disclosure for Shariah Commercial Bank. Population in this study are all Shariah Commercial Bank in Indonesia During 2010-2014. The total number of sample in this study were seven Shariah Commercial Bank with method is purposive sampling. This research used content analysis method to analysis ISR disclosure bank's to annual report. This research uses panel data regression analysis technique. The result shows that simultaneously the company size, company age, profitability, and liquidity have significant effect toward of ISR disclosure. Company Age and profitability partially have significant effect toward of ISR disclosure, while company size, and liquidity partially doesn't have significant effect toward of ISR disclosure.
\end{abstract}

Keywords: company size, company age, profitability, liquidity and Islamic Social Reporting (ISR) Disclosure.

\section{PENDAHULUAN}

\section{Latar Belakang}

Pada saat industri berkembang setelah terjadinya revolusi industri kebanyakan perusahaan masih memfokuskan dirinya sebagai suatu organisasi yang mencari profitabilitas saja. Mereka memandang bahwa sumbangan bagi masyarakat cukup diberikan dalam bentuk penyediaan lapangan pekerjaan, pemenuhan kebutuhan masyarakat melalui produk dan jasa, serta pembayaran pajak kepada negara (Wibisono, 2007: 4).

Namun pemberian sumbangan tersebut tidak mengatasi isu sosial dan lingkungan yang diakibatkan oleh kegiatan operasional perusahaan. Adanya masalah tersebut mendasari lahirnya teori stakeholders. Dimana menurut Othman et.al (2009) teori stakeholders menyatakan manajemen memberikan informasi kepada pengguna sehingga dapat mempertahankan kesuksesan perusahaan. Definisi stakeholders itu sendiri adalah pihak atau kelompok yang berkepentingan, baik secara langsung maupun tidak langsung berada pada aktivitas perusahaan, dan karena kelompok tersebut dapat mempengaruhi dan dipengaruhi oleh perusahaan (Wibisono, 2007: 96). Sehingga dapat dikatakan bahwa terdapat peran penting stakeholders bagi keberlanjutan perusahaan.

Dalam Islam, fenomena isu sosial dan lingkungan yang disebabkan oleh

1) Jurnal ini merupakan bagian dari skripsi dari Nia Fajriyatun Nadlifiyah, NIM : 041211431174 , yang diuji pada 3 Juni 2016 
kegiatan operasional perusahaan sebenarnya dibahas dalam Al-Qur'an dan Hadits. Sebagaimana dalam firman Allah dalam surat Al-Baqarah (2) ayat 273:

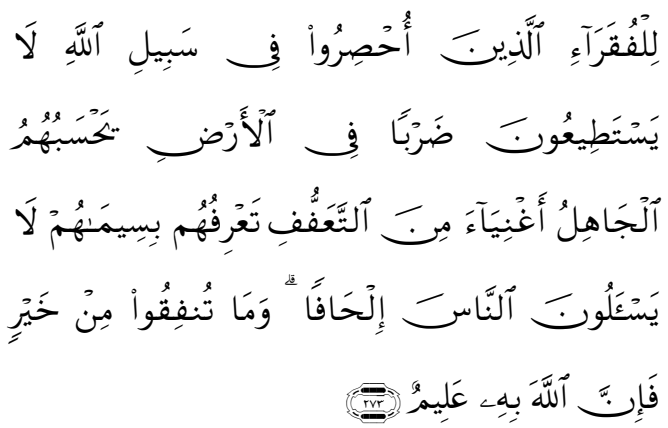

li-l-fuqarā i lladhīna 'Uhșirū fì sabili llāhi lā yastațīùna darban fi l-'arḍi yahsabuhumu l-jāhilu 'aghniyā 'a mina t-ta'affufi ta'rifuhum bi-simāhum lā yas'alūna n-nāsa ilhāfan wa-mā tunfiqū min khayrin fa-'inna llāha bihī alim

Artinya: "(Berinfaglah) kepada orang-orang fakir yang terikat (oleh iihad) di jalan Allah. Mereka tidak dapat (berusaha) di bumi. Orang yang tidak tahu menyangka mereka orang kaya karena memelihara diri dari minta-minta. Kamu kenal mereka dengan melihat sifat-sifatnya, mereka tidak meminta kepada orang secara mendesak. Dan, apa saja harta yang baik yang kamu nafkahkan (di jalan Allah), maka sesungguhnya Allah Maha Mengatahui". (DEPAG.RI.2010: 47)

Jika ayat tersebut dikaitkan dengan isu sosial maka terdapat hubungan berupa kewajiban untuk mendistribusikan kekayaan, yang berdampak pada solusi atas isu sosial yang ada dimasyarakat sekitar. Kemudian mengenai isu lingkungan Allah berfirman dalam surat Al-A'raf (7) ayat 56:

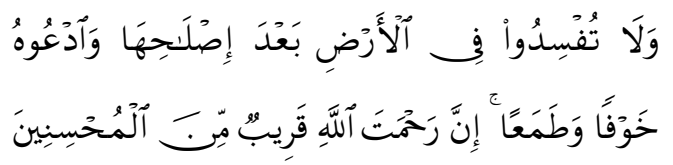

wa-lā tufsidū fì l- 'arḍi ba 'da 'ișlāhihāa wa-d 'ühu khawfan wa-țama an 'inna rahmat llähi qaribun mina l-muhsinin

Artinya: "Dan janganlah kamu membuat kerusakan dimuka bumi, sesudah (Allah) memperbaikinya dan Berdo'a-lah kepada-Nya dengan rasa takut (tidak akan diterima) dan harapan (akan dikabulkan). Sesungguhnya rahmat Allah Amat dekat kepada orang-orang yang berbuat baik". (DEPAG.RI.2010: 157)

Adanya kedua ayat Al-Qur'an tersebut yang membahas mengenai fenomena isu sosial dan lingkungan, sebenarnya adalah landasan bagi perusahaan untuk melakukan tanggungjawab sosial. Sehingga hal tersebut memunculkan suatu teori yang disebut dengan Shariah Enterprise Theory (SET). Pada teori ini dijelaskan bahwa manusia sebagai kholifah dimuka bumi mempunyai tanggungjawab untuk memegang amanah dari Allah sebagai pemilik mutlak dari seluruh isi bumi dan langit untuk menggunakan dengan cara dan tujuan yang telah ditetapkan.

Pada penelitian ini fokus pada Bank Umum Syariah (BUS) di Indonesia. adanya perkembangan tersebut maka akan meningkat pula persaingan yang cukup ketat, sehingga mengharuskan bank syariah terus memperbaiki kinerjanya (Istiani, 2015). Dimana menurut Istiani (2015) tantangan utama bagi bank syariah saat ini adalah mewujudkan kepercayaan dari para stakeholders, karena kepercayaan dari stakeholders akan memberikan dampak positif bagi perkembangan bank syariah itu sendiri.

Salah satu upaya bank syariah dalam meningkatkan kepercayaan 
Nadlifiyah, et al/Jurnal Ekonomi Syariah Teori dan Terapan Vol. 4 No. 1 Januari 2017: 44-61; ANALISIS PENGARUH KINERJA PERUSAHAAN TERHADAP PENGUNGKAPAN ISR BANK UMUM SYARIAH TAHUN 2010-2014

stakeholders-nya adalah dengan memberikan informasi kinerja sosial melalui laporan tahunan bank syariah. Hal tersebut dikarenakan stakeholders mempunyai hak atas informasi tentang seluruh kegiatan operasional perbankan syariah, termasuk aspek sosial dan lingkungan (Istiani, 2015).

Dalam laporan tahunan Bank Umum Syariah (BUS) harus menyampaikan informasi mengenai kinerja suatu bank syariah dalam kurun waktu satu tahun. Sejauh ini masih belum ada standar baku pengungkapan kinerja perbankan syariah di Indonesia sesuai ketentuan syariah. Hal ini dikarenakan bank syariah masih menggunakan indeks pengungkapan Global Reporting (GRI) atau ISO 26000 (International Standart Organization) padahal standar tersebut belum mengadopsi prinsip-prinsip syariah. Sehingga pada tahun 2002 muncul indeks pengungkapan ISR yang dikemukakan oleh Haniffa (2002).

$$
\text { Menurut Haniffa }
$$

pengungkapan ISR adalah perluasan dari kinerja sosial perusahaan yang meliputi harapan masyarakat tidak hanya mengenai peran perusahaan dalam perekonomian, tetapi juga peran perusahaan dalam pespektif spiritual.

Pada penelitian akan menganalisis laporan tahunan Bank Umum Syariah (BUS) menggunakan pengungkapan ISR. Hal tersebut dikarenakan pada penelitian terdahulu melakukan analisis laporan tahunan perusahaan, sehingga masih belum banyak penelitian yang membahas tentang analisis laporan tahunan pada BUS menggunakan pengungkapan ISR.

Sebagaimana penelitian yang dilakukan oleh Sembiring (2003), Haniffa dan Cooke (2005), Othman, et, al (2009), Raditya (2012), Astuti (2013), dan Permatasari (2015). Penelitian tersebut menghasilkan beberapa variabel independen yang mempengaruhi pengungkapan ISR yakni ukuran perusahaan, profitabillitas, komposisi dewan perusahaan, tipe industri, likuiditas, tipe kepemilikan, leverage, dan umur perusahaan.

$\begin{array}{crr}\text { Dari } & \text { beberapa } & \text { variabel } \\ \text { independen } & \text { tersebut } & \text { peneliti } \\ \text { menggunakan } & \text { empat } & \text { variabel }\end{array}$
independen berupa ukuran perusahaan, umur perusahaan, profitabilitas, dan likuiditas. Hal tersebut dikarenakan ke empat variabel menunjukkan pengaruh signifikan terhadap pengungkapan ISR. Sehingga penelitian ini membahas tentang "Pengaruh Ukuran Perusahaan, Umur Perusahaan, Profitabilitas, dan Likuiditas Terhadap Pengungkapan Islamic Social Reporting (ISR) pada Bank Umum Syariah (BUS) di Indonesia tahun 2010$2014 "$.

Dari latar belakang diatas, maka rumusan masalah pada penelitian ini terdiri dari:

1. Secara simultan adakah pengaruh ukuran perusahaan, umur perusahaan, profitabilitas, dan likuiditas terhadap pengungkapan ISR? 
2. Secara parsiaal adakah pengaruh ukuran perusahaan, umur perusahaan, profitabilitas, dan likuiditas terhadap pengungkapan ISR?

\section{TINJAUAN PUSTAKA}

Pada penelitian ini menggunakan teori stakeholders dan Shariah Enterprise Theory. Menurut Othman et.al (2009) teori stakeholders menyatakan bahwa manajemen memberikan informasi kepada para pengguna sehingga dapat mempertahankan kesuksesan perusahaan. Hal tersebut dikarenakan keberadaan, keberlanjutan, dan kesuksesan suatu perusahaan bergantung pada dukungan terus-menerus dari para pemangku kepentingan (Ullman, 1985) dalam (Othman et.al, 2009). Oleh karena itu, penting bagi manajemen untuk mengidentifikasi, mengevaluasi dan menyebarkan informasi yang berkaitan dengan informasi sosial dan lingkungan sesuai dengan permintaan dari para pemangku kepentingan (Zain, 1999) dalam (Othman et.al, 2009).

\section{Sedangkan Shariah Enterprise} Theory (SET) menggunakan prinsip yang berbentuk pertanggungjawaban utamanya kepada Allah, yang kemudian dijabarkan lagi pada bentuk pertanggungjawaban (horizontal) pada umat manusia dan lingkungan alam (Triyuwono, 2006: 353). Sehingga pada teori ini terdapat pandangan bahwa perusahaan berbasis syariah dalm hal ini bank syariah merupakan bagian dari kholifah Allah yang diberi amanah untuk mengelolah sumber daya dan mendistribusikannya pada seluruh makhluk dimuka bumi secara adil (Slamet, 2001: 268) dalam (Triyuwono, 2006: 353354).

Haniffa (2002) berpendapat bahwa pengungkapan laporan sosial perusahaan pada sistem ekonomi konvensional hanya berfokus pada aspek material dan moral, padahal seharusnya aspek spiritual juga dijadikan sebagai fokus dalam pengungkapan laporan sosial. Ini dikarenakan masyarakat muslim mempunyai hak untuk mengetahui berbagai informasi mengenai aktivitas organisasi. Hal ini dilakukan untuk melihat apakah perusahaan tetap melakukan kegiatannya sesuai syariah dan mencapai tujuan yang telah ditetapkan (Baydoun dan Willet, 1997) dalam Fitria dan Hartanti (2010). Sehingga dengan adanya hal tersebut, muncullah pengungkapan laporan sosial yang sesuai dengan prinsip Islam yakni Islamic Social Reporting (ISR).

Pada penelitian ini terdapat enam tema ISR berupa keuangan dan investasi, jasa dan produk, tenaga kerja, lingkungan, masyarakat, dan tata kelola perusahaan:

1. Kevangan dan investasi: pada tema ini perusahaan dilarang melakukan riba, kegiatan yang mengandung ketidakjelasan (gharar), kebijakan atas piutang tak tertagih, current value balance sheet, dan value added statemant. 
2. Jasa dan produk: Pada tema ini terdapat tanggung jawab bagi perusahaan untuk mengungkapkan semua produk dan jasa yang masuk dalam kategori haram (dilarang) seperti minuman keras, babi, perjudian. Karena pengungkapkan tersebut sangat dibutuhkan oleh masyarakat muslim yang peduli dengan status halal dan thoyib sebuah produk dan jasa (Haniffa, 2002).

3. tenaga kerja: Segala sesuatu yang berkaitan dengan tenaga kerja pada kontek pengungkapan ISR berasal dari konsep etika dan keadilan. Seorang tenaga kerja harus diperlakukan secara adil dan diberikan haknya. Dalam tema ini masyarakat Islam perlu mengetahui bagaimana perusahaan menangani tenaga kerja secara adil melalui pengungkapan informasi seperti upah, sifat pekerjaan, jam kerja per hari, cuti tahunan, kesehatan dan kesejahteraan, kebijakan mengenai hal keagamaan seperti: waktu sholat dan tempat sholat, dukungan kepada tenaga kerja berupa pendidikan dan pelatihan, kesempatan yang sama, dan lingkungan kerja.Sesuai dengan penjelasan diatas, maka kriteria yang ditentukan pada pengungkapan tema tenaga kerja sebagai berikut: Karakteristik pekerjaan meliputi: jumlah jam kerja, hari libur, dan rasio gaji, Program pendidikan dan pelatihan bagi karyawan, Kesempatan yang sama, Keterlibatan karyawan, Kesehatan dan keselamatan kerja, Lingkungan kerja, Perekrutan khusus, dan Terdapat tempat ibadah untuk karyawan
4. Masyarakat: Pada tema ini konsep dasar dari ummah, amanah, dan adl (Haniffa, 2002). Dimana pada konsep tersebut menekankan pada pentingnya saling berbagi dan saling meringankan beban orang lain di dalam sebuah masyarakat. perusahaan harus mengungkapkan perannya dalam meningkatkan pembangunan ekonomi dan mengatasi masalah sosial (misalnya: buta huruf, beasiswa dIII) dari masyarakat dimana perusahaan beroperasi.Sesuai dengan penjelasan diatas, maka kriteria yang ditentukan pada pengungkapan tema masyarakat yakni:Shodaqoh, Donasi, Wakaf, Qard hasan, Zakat atau sumbangan dari karyawan atau nasabah, Pendidikan (pendirian sekolah; bantuan pada sekolah dalam finansial atau non finansial; beasiswa), Bantuan kesehatan, Pemberdayaan ekonomi, Kepedulian terhadap anak yatim piatu, Pembangunan atau renovasi masjid, Kegiatan kepemudaan, Kegiatan sosial lainnya (pemberian buku, mudik bareng, dan lain-lain), Spongsor acara kesehatan, olahraga, edukasi dan lain-lain, Pembangunan /renovasi masjid, Kegiatan kepemudaan, Kegiatan sosial lainnya.

5. Lingkungan: Pada tema ini konsep yang mendasari adalah mizan, i'tidal, khalifah, dan akhirat. Perusahaan yang kegiatan operasionalnya berkaitan dengan alam, diharuskan untuk tidak melakukan kegiatan yang merusak dan membahayakan lingkungan alam. Karena sangat penting bagi seluruh makhluk hidup untuk melindungi alam sekitar 
(Haniffa, 2002). Kriteria yang ditentukan pada pengungkapan tema lingkungan sebagai berikut: Kampanye go green, Konservasi lingkungan, Perlindungan terhadap flora dan faunayang liar atau terancam punah, Polusi, Perbaikan dan pembuatan sarana umum, Audit lingkungan, dan Kebijakan manajemen lingkungan.

6. Tata kelola perusahaan: kriteria yang ditentukan pada pengungkapan tema masyarakat sebagai berikut: Profil dan strategi organisasi, Struktur organisasi, Pelaksanaan tugas dan tanggung jawab dewan komisaris, Kelengkapan dan pelaksanaan tugas komite, Pelaksanaan tugas dan tanggung jawab DPS, Fungsi kepatuhan bank, Fungsi audit Internal, Fungsi audit Eksternal, dan Transparansi kondisi keuangan dan non keuangan.

Berikut adalah penelitian terdahulu yang menjadi acuan peneliti dalam melakukan penelitian ini:

1. Penelitian yang dilakuan oleh Othman et.al (2009) yang berjudul Determinant of Islamic Social Reporting Among Top shariah-Approved Companies in Bursa malaysia. Pada penelitian ini menggunakan teknik analisis regresi linier berganda sehingga terdapat variabel independen (ukuran perusahaan, profitabilitas, komposisi dewan perusahaan dan tipe industri) terhadap variabel dependen (pengungkapan ISR). Hasilnya menunjukkan terdapat pengaruh positif signifikan antara ikuran perusahaan, profitabilitas, dan komposisi dewan perusahaan terhadap indek ISR. Terdapat perbedaan antara penelitian Othman et.al (2009) dengan penelitian selanjutnya, yakni 1) Pada variabel independen yang digunakan penelitian selanjutnya tidak menggunakan komposisi dewan perusahaan dan tipe industri, namun menggunakan likuiditas dan umur perusahaan. 2) Pada penelitian selanjutnya menggunakan analisis regresi data panel. 3)Pada penelitian selanjutnya menggunakan Bank Umum syariah Bukan Perusahaan yang terdaftar di indeks Islami.

2. Penelitian yang dilalukan Astuti (2013) yang berjudul Pengaruh profitabilitas, likuiditas, dan leverage terhadap pengungkapan ISR studi empiris pada perusahaan yang terdaftar di Jll tahun 2010-2012. Pada penelitian ini menggunakan teknik analisis regresi linier berganda sehingga terdapat variabel independen (profitabilitas, likuiditas dan leverage) terhadap variabel dependen (pengungkapan ISR). Hasilnya menunjukkan Secara simultan, terdapat pengaruh positif signifikan antara profitabilitas, likuiditas dan leverage terhadap pengungkapan ISR. Terdapat perbedaan antara penelitian Astuti (2013) dengan penelitian selanjutnya, yakni 1) Pada variabel independen yang digunakan penelitian selanjutnya tidak menggunakan leverage, namun menggunakan ukuran perusahaan 
dan umur perusahaan. 2) Pada penelitian selanjutnya menggunakan analisis regresi data panel. 3)Pada penelitian selanjutnya menggunakan Bank Umum syariah Bukan Perusahaan yang terdaftar di indeks Islami.

3. Penelitian yang dilakukan Raditya (2012) yang berjudul analisis Faktor yang mempengaruhi tingkat pengungkapan ISR pada perusahaan yang terdaftar di DES. Pada penelitian ini menggunakan teknik analisis regresi linier berganda sehingga terdapat variabel independen (penerbitan sukuk; ukuran perusahaan; profitabilitas; jenis industri; umur perusahaan) terhadap variabel dependen (pengungkapan ISR). Hasilnya menunjukkan terdapat pengaruh positif signifikan antara profitabilitas, likuiditas dan leverage terhadap pengungkapan ISR. Terdapat perbedaan antara penelitian Astuti (2013) dengan penelitian selanjutnya, yakni 1) Pada variabel independen yang digunakan penelitian selanjutnya tidak menggunakan leverage, namun menggunakan ukuran perusahaan dan umur perusahaan. 2) Pada penelitian selanjutnya menggunakan analisis regresi data panel. 3)Pada penelitian selanjutnya menggunakan Bank Umum syariah Bukan Perusahaan yang terdaftar di indeks Islami.

4. Penelitian yang dilakukan oleh Istiani (2015) yang berjudul Pengaruh ukuran perusahaan, Profitabilitas, Likuiditas, dan Leverage terhadap indeks Islamic Social Reporting pada Bank Umum Syariah di Indonesia periode 20112014, Teknik analisis pada penelitian ini menggunakan regresi data panel sehingga terdapat variabel independen; ukuran perusahaan, profitabilitas, likuiditas dan leverage. Sedangkan dependen berupa pengungkapan ISR. Hasilnya menunjukkan secara simultan ukuran perusahaan, profitabilitas, likuiditas dan leverage berpengaruh signifikan terhadap indeks pengungkapan ISR. Sedangkan secara parsial hanya ukuran perusahaan yang berpengaruh signifikan terhadap indeks pengungkapan ISR. Terdapat perbedaan antara penelitian Istiani (2015) dengan penelitian selanjutnya, yakni 1) Pada variabel independen yang digunakan penelitian selanjutnya tidak menggunakan leverage, namun menggunakan umur perusahaan. 2) Sampel yang digunakan pada penelitian ini 10 sedangkan pada penelitian selanjutnya 7 bank syariah. 3) periode pada penelitian terdahulu dari 2011-2014, sedangkan penelitian selanjutnya pada tahun 2010-2014.

Dari beberapa penelitian terdahulu tersebut, berikut uji hipotesis yang diajukan:

$\mathrm{Hl}$ : Secara simultan ukuran perusahaan, umur perusahaan, profitabilitas dan likuiditas berpengaruh signifikan terhadap pengungkapan ISR 
H2: Secara parsial ukuran perusahaan, umur perusahaan, profitabilitas dan likuiditas berpengaruh signifikan terhadap pengungkapan ISR

\section{METODE PENELITIAN}

Pendekatan yang digunakan dalam penelitian ini adalah pendekatan kuantitatif. Dengan menguji sebab akibat pada variabel independen dan variabel dependen.

\section{Definisi Operasional Variabel Indepeden Ukuran perusahaan}

Data pada total aset didapatkan dari laporan keuangan perusahaan yang menjadi sampel penelitian. Total aset sebagai mana dimaksud akan dibentuk menjadi logaritma natural (In) untuk menyamakan total aset dengan bentuk variabel lainnya.Secara sistematis tersebut dapat diformulasikan sebagai berikut:

Ukuran perusahaan $=\operatorname{Ln}$ (Total Aset)

(Sumber: Permatasari, 2015)

\section{Umur Perusahaan}

Menurut Haniffa dan Cooke (2005) umur perusahaan dapat diukur sejak perusahaan terdaftar di bursa Malaysia. Namun karena penelitian ini menggunakan perbankan syariah maka umur perusahaan diukur sejak bank syariah menjadi anggota Bank Umum Syariah (BUS). Sehingga persamaan umur perusahaan sebagai berikut:

Umur Perusahaan = Menjadi Anggota BUS

\section{Profitabilitas}

Menurut Muhammad (2015: 254) Rasio profitabilitas ini dapat menunjukkan tingkat efektivitas yang dicapai melalui usaha operasional bank. Dimana pada penelitian ini memfokuskan pada rasio Return On Asset (ROA. Menurut Muhammad (2015: 254) rasio Return On Asset (ROA) merupakan kemampuan bank dalam mengelola dana diinvestasikan dalam keseluruhan aktiva yang menghasilkan keuntungan. Secara sistematis rasio tersebut dapat diformulasikan sebagai berikut:

ROA $=\frac{\text { Laba Bersih Setelah Pajak }}{\text { Total Aset }}$

(Sumber: Sudana, 2011: 22)

\section{Likuiditas}

Likuiditas merupakan salah satu rasio keuangan yang mengukur kemampuan perusahaan untuk memenuhi kewajiban jangka pendek (Sudana, 2011: 21). Dimana pada penelitian ini fokus pada Loan to Deposito Ratio (LDR) atau disebtu dengan Financing to Deposit Ratio (FDR). Menurut Muhammad (2015: 253) FDR dapat menunjukkan kesehatan bank dalam memberikan pembiayaan. Dimana tingkat FDR suatu bank dapat menunjukkan kemampuan bank dalam menyalurkan DPK yang dihimpun oleh bank yang bersangkutan. Secara sistematis rasio tersebut dapat diformulasikan sebagai berikut:

FDR = Total pembiayaan yang diberikan

Bank Total Dana Pihak Ketiga

(Sumber: Muhammad, 2015: 253)

Definisi Operasional Variabel dependen Indeks Pengungkapan ISR 
Untuk melakukan penilaian pengungkapan ISR dilakukan dengan menggunakan variabel dikotomi atau variabel dummy yakni dengan memberikan skor 0-1, dimana:

1. skor 0: jika perusahaan tidak mengungkapkan item pada daftar pertanyaan

2. skor 1: jika perusahaan mengungkapkan item pada daftar pertanyaan.

Selanjutnya skor dari keseluruhan item dijumlahkan untuk memperoleh keseluruhan skor yang diungkapkan setiap perusahaan (Haniffa dkk,(2005). Jika perusahaan melakukan pengungkapan item secara penuh yakni berupa 47 item, maka item yang diungkapkan perusahaan mencapai nilai maksimal (Othman dan Thani, 2010). Berikut rumus perhitungan CSDI menurut Haniffa dan Cooke (2005) :

CSDIj

$$
\frac{\sum_{t=1}^{n j} x_{i j}}{n j}
$$

Keterangan:

nj = jumlah item yang diharapkan oleh perusahaan

Xij $\quad=1=$ jika item i diungkapkan; $0=$ jika item i tidak diungkapkan

Dengan demikian, $0 \leq \mathrm{lj} \leq 1$.

\section{Jenis dan Sumber data}

Jenis dan sumber data yang digunakan adalah data sekunder, dari laporan tahunan bank syariah yang dipublis di website resmi bank syariah.
Populasi

Populasi pada penelitian ini adalah seluruh Bank Umum Syariah (BUS) yang terdaftar di Bank Indonesia tahun 20102014.

\section{Sampel}

Teknik sampling yang digunakan adalah purposive sampling. Berikut penjelasan mengenai kriteriapengambilan sampel:

Tabel 1.

Kriteria Pengambilan Sampel

\begin{tabular}{|c|c|c|}
\hline No & Kriteria & Jumlah \\
\hline 1 & $\begin{array}{l}\text { Bank Syariahyangterdaftar sebaga inggota BUS } \\
\text { pada Bank Indonesia tahum 2010-2014 }\end{array}$ & 12 \\
\hline 2 & $\begin{array}{l}\text { Bank Svariahyangmenerbitkan laporan tahuman } \\
\text { secara konsisten pada tahun 2010-2014 }\end{array}$ & 10 \\
\hline 3 & Bank syariahyangmemilikilaba positif & 8 \\
\hline 4 & $\begin{array}{l}\text { Bank syariahyangmelakukan pengungkapan secara } \\
\text { lengkap. }\end{array}$ & 7 \\
\hline \multicolumn{2}{|c|}{ Jumlah sampel $(7 \times 5(\operatorname{tahun} 2010-2014))$} & 35 \\
\hline
\end{tabular}

Sumber: Data diolah, 2016

\section{Teknik Analisis}

Penelitian ini menggunakan program Eviews ${ }^{\circledR 8}$ versi 2013. Kemudian untuk jenis data yang digunakan pada penelitian ini adalah data panel.

\section{Pemilihan Metode Estimasi Data Panel}

Menurut Ajia, dkk (2011: 51) ada tiga metode yang digunakan untuk bekerja dengan data panel, yakni sebagai berikut:

1. Pooled Least Square (PLS)

2. Fixxed Effect (FE)

3. Pendekatan Random Effect (RE) 
Uji Pemilihan Model Estimasi Data Panel

Uji Chow

Menurut Ajija, dkk (2011: 52-53) Hipotesis pada uji chow adalah sebagai berikut:

$\mathrm{HO}$ : Pooled Lest Square (PLS)

$\mathrm{Hl}$ : Fixed effect Model (FEM)

Jika memperoleh hasil nilai cross section $F<$ tingkat keyakinan $(a)=5 \%$, maka menolak $\mathrm{HO}$ dan menerima $\mathrm{Hl}$ sehingga menggunakan Fixed effect Model (FEM).

\section{Uji Hausman}

Hipotesis pada uji hausman adalah sebagai berikut:

$\mathrm{H}_{\mathrm{o}}$ : Random Effect Model

$\mathrm{H}_{1}$ : Fixed Effect Model

Jika memperoleh hasil nilai uji hausman $p$-value < a, atau signifikan pada $\mathrm{a}=5 \%$, maka menolak $\mathrm{HO}$ dan menerima $\mathrm{H} l$ yang menyatakan kita harus memilih Model Fixed Effect.

\section{Uji Koefisien $\mathbf{R}^{2}$}

Uji koefisien determinasi digunakan untuk melihat seberapa besar pengaruh variabel independen terhadap variabel dependen. Dimana Nilai $R^{2}$ mempunyai interval 0 sampai $1\left(0<R^{2}<1\right)$. Hal tersebut mengartikan bahwa semakin besar nilai $R^{2}$ (mendekati 1), maka semakin baik hasil untuk model regresi tersebut, namun jika nilai $R^{2}$ mendekati 0 , maka variabel secara keseluruhan tidak dapat menjelaskan variabel independen (Ajija, dkk, 2011:34).

\section{Uji Hipotesis}

Uji hipotesis yang digunakan pada penelitian ini menggunakan uji $t$ dan uji $\mathrm{f}$.
Berikut penjelasan kedua uji tersebut (Ghozali dan Ratmono, 2013: 61-63):

1. Uji $F$ dilakukan untuk mengetahui pengaruh variabel independen secara simultan/ bersama-sama terhadap variabel dependen. Dasar pengambilan keputusan dilakukan dengan cara membandingkan nilai signifikansi. Jika nilai hitung $F>$ nilai $F$ tabel, maka $\mathrm{HO}$ ditolak yang berarti $\mathrm{X}_{1}$ berpengaruh signifikan terhadap $Y$, begitupun seterusnya.

2. Uji $\dagger$ dilakukan untuk mengetahui seberapa jauh pengaruh variabel independen secara individual/parsial terhadap variabel dependen. Dasar pengambilan keputusan dilakukan dengan cara membandingkan nilai signifikansi. Jika nilai hitung $\dagger>$ nilai † tabel, maka $\mathrm{HO}$ ditolak yang berarti $X_{1}$ berpengaruh signifikan terhadap $Y$, begitupun seterusnya.

\section{HASIL DAN PEMBAHASAN}

\section{Hasil Uji Statistik Deskriptif}

Berikut hasil uji statistik deskriptif dilihat pada tabel 4.2:

Tabel 2.

Statistik Deskriptif

\begin{tabular}{|c|c|c|c|c|c|c|}
\hline No. & Variabel & N & Min & Max & Mean & $\begin{array}{c}\text { Standar } \\
\text { Deviasi }\end{array}$ \\
\hline 1 & $\mathrm{Y}$ & 35 & 51,06 & 87,23 & 71,49 & 11,31 \\
\hline 2 & $\mathrm{X}_{1}$ & 35 & 336.676 & 669.420 .000 & 14.010 .750 & 19041290,6 \\
\hline 3 & $\mathrm{X}_{2}$ & 35 & 1 & 23 & 8,42 & 6,57 \\
\hline 4 & $\mathrm{X}_{3}$ & 35 & 0,08 & 3,81 & 1,13 & 0,79 \\
\hline 5 & $\mathrm{X}_{4}$ & 35 & 68,93 & 103,07 & 88,99 & 8,08 \\
\hline
\end{tabular}

Sumber: Data diolah, 2016 
Pada tabel 2 dapat dijelaskan bahwa jumlah data (N) yang digunakan adalah 35 data. Variabel ISR mempunyai jumlah rata-rata yaitu sebesar $71,49 \%$. Terdapat anggota BUS yang hanya mengungkapkan ISR sebesar 51,06\%. Walaupun demikian terdapat sampel BUS yang mengungkapkan ISR tinggi sebesar 87,23\%. Hal ini menunjukkan adanya kesadaran yang cukup tinggi dari perbankan syariah dalam melakukan pengungkapan ISR. Dan secara keseluruhan, standar deviasi skor ISR bernilai $11,31 \%$. Hal ini bearti skor ISR menyimpang kurang lebih sebesar 11,31\% dari rata-rata ISR secara menyeluruh.

Variabel ukuran perusahaan (X1) yang diukur dengan total aset mempunyai nilai rata-rata sebesar $\mathrm{Rp}$ 14.010.750. Nilai standar deviasi Rp 19041290,6, dengan kata lain nilai total aset memiliki variabilitas sebesar $\mathrm{Rp}$ 19041290,6 atau menyimpang kurang lebih Rp 19041290,6. Dari rata-rata total aset secara keseluruhan. Total aset terendah sebesar Rp 336.676 dan nilai total aset tertinggi sebesar Rp 66.942.000. Sedangkan variabel umur perusahaan (X2) mempunyai nilai rata-rata sebesar $8,42 \%$. Sedangkan nilai standar deviasi $6,57 \%$, dengan kata lain nilai umur memiliki variabilitas sebesar $6,57 \%$ atau menyimpang kurang lebih 6,57\%. Dari rata-rata umur secara keseluruhan terendah sebesar 1 dan nilai umur tertinggi sebesar 23.

Variabel profitabilitas (X3) yang diukur dengan Return On Aset (ROA) mempunyai nilai rata-rata menghasilkan laba bersih sebesar 1,13\% dari total aset yang dimiliki. Nilai standar deviasi 1,23\%, dengan kata lain nilai ROA memiliki variabilitas sebesar $1,23 \%$ atau menyimpang kurang lebih 1,23\%. Dari rata-rata ROA secara keseluruhan. ROA terendah sebesar $0,08 \%$ dan nilai ROA tertinggi sebesar $3,81 \%$. Sedangkan variabel likuiditas (X4) yang diukur dengan Financing to Deposit Ratio (FDR) mempunyai nilai rata-rata sebesar $88,99 \%$. Nilai standar deviasi $8,08 \%$, dengan kata Iain nilai FDR memiliki variabilitas sebesar 8,08\% atau menyimpang kurang lebih 8,08\%. Dari rata-rata FDR secara keseluruhan. FDR terendah sebesar 68,93\% dan nilai FDR tertinggi sebesar 103,07\%.

\section{Hasil Uji Data Panel \\ Uji Chow}

Berikut hasil Uji Chow dapat dilihat pada tabel 4.3:

Tabel 3.

Uji Chow

\begin{tabular}{|c|c|c|c|}
\hline Effects Test & Statistic & d.f. & Prob. \\
\hline Cross-section F & 15.117040 & $(6,24)$ & 0.0000 \\
\hline Cross-section Chi-square & 54.750000 & 6 & 0.0000 \\
\hline
\end{tabular}

Sumber: Output Eviews

Hasil output pada tabel 4.3 dapat dilihat bahwa nilai probabilitas cross section $F$ adalah $0.000<0,05$, maka $\mathrm{HO}$ ditolak, dan menerima $\mathrm{Hl}$ yang berarti model fixed effect lebih tepat digunakan daripada model common effect.

\section{Uji Hausman}


Berikut hasil Uji hausman dapat dilihat pada tabel 4.3:

Tabel 4.

Uji Hausaman

Correlated Random Effects - Hausman Test

Pool: Untitled

Test cross-section random effects

Test Summary Chi-Sq. Statistic Chi-Sq.df. Prob

\begin{tabular}{llll}
\hline Cross-section random & 24.754157 & 4 & 0.0007
\end{tabular}

Sumber: Hasil penelitian, 2016 (diolah)

Hasil pada tabel 4 dapat dilihat bahwa nilai probabilitas cross section adalah 0,0001<0,05, maka HO ditolak dan menerima $\mathrm{H} 1$ yang berarti menggunakan model fixed effect.

\section{Koefisien Determinasi $\left(\mathbf{R}^{2}\right)$}

Berikut hasil Uji koefisien determinasi $\left(R^{2}\right)$ dapat dilihat pada tabel 4.5:

Tabel 5.

Uji Koefisien Determinasi

\begin{tabular}{|c|c|c|c|c|}
\hline Variable & Coemicient & Sta. Error & t-Statistic & Prota \\
\hline \multirow{3}{*}{ 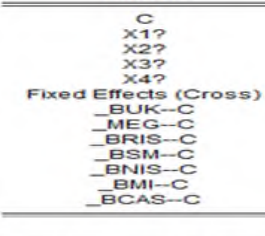 } & $\begin{array}{r}167.6603 \\
-8.490844 \\
5.243542 \\
3.040371 \\
-0.076554\end{array}$ & \multirow[t]{2}{*}{$\begin{array}{l}9235374 \\
6.565475 \\
1.778904 \\
1.461316 \\
0.114435\end{array}$} & \multirow[t]{2}{*}{$\begin{array}{r}1.815414 \\
-1293257 \\
2947625 \\
2080570 \\
-0.668973\end{array}$} & \multirow[t]{2}{*}{$\begin{array}{l}0.0820 \\
0.2082 \\
0.0010 \\
0.0409 \\
0.5099\end{array}$} \\
\hline & $\begin{array}{l}5.788974 \\
-21.55161 \\
21.66419 \\
-3.447892 \\
30.32284 \\
-37.99899 \\
5.222492\end{array}$ & & & \\
\hline & \multicolumn{4}{|c|}{ Efrects Specincation } \\
\hline \multicolumn{5}{|c|}{ Cross-section nxed (dummy variables) } \\
\hline $\begin{array}{l}\text { R-squared } \\
\text { Adjusted R-squared } \\
\text { S.E. of regression } \\
\text { Sum squared resid } \\
\text { Log likelihood } \\
\text { F-statistic } \\
\text { Prob(F-statistic) }\end{array}$ & $\begin{array}{l}0.941120 \\
0.916586 \\
3.265316 \\
255.8949 \\
-84.47768 \\
38.36057 \\
0.000000\end{array}$ & $\begin{array}{l}\text { Mean depen } \\
\text { S.D. depend } \\
\text { Akaike info c } \\
\text { Schwarz crite } \\
\text { Hannan-Quir } \\
\text { Durbin-Wats }\end{array}$ & $\begin{array}{l}\text { ent var } \\
\text { nt var } \\
\text { terion } \\
\text { ion } \\
\text { pcriter- } \\
\text { n stat }\end{array}$ & $\begin{array}{l}71.49029 \\
11.30592 \\
5.455867 \\
5.944691 \\
5.624609 \\
1.439276\end{array}$ \\
\hline
\end{tabular}

Sumber: Hasil penelitian, 2016 (diolah)

Hasil pada tabel 5 menunjukkan

nilai Adjusted $R$ Square pada model regresi adalah 0,916586 yang menunjukkan kemampuan variabel independen $\left(X_{1}, X_{2}, X_{3}\right.$, dan X4) dapat menjelaskan variabel dependen $(Y)$ adalah sebesar $91 \%$ sedangkan sisanya 9\% dijelaskan oleh variabel lain yang tidak termasuk dalam penelitian ini.

Pengujian Hipotesis

Uji Signifikan Simultan (Uji F)

Tabel 6.

Uji Signifikan Simultan (Uji F)

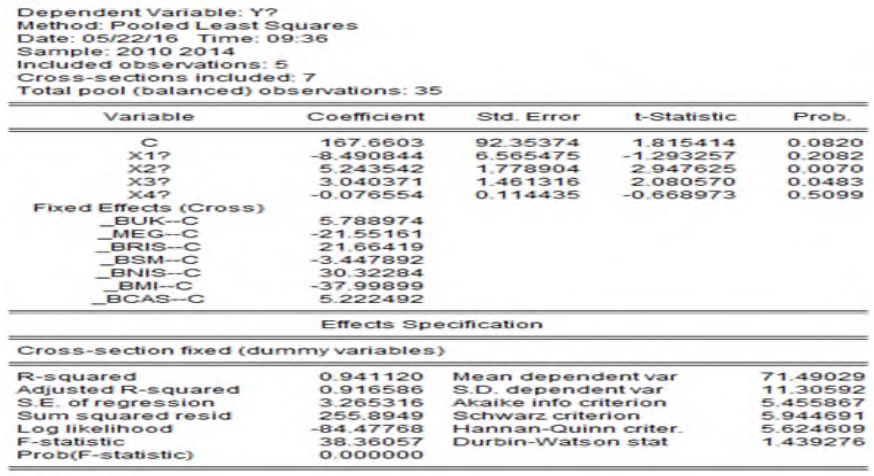

Sumber: Hasil penelitian, 2016 (diolah)

Hasil tabel 6 menunjukkan nilai $F$ statistik sebesar 38,36057, dan nilai probabilitas $0,0000<0,05$ maka dapat disimpulkan bahwa menolak $\mathrm{HO}$ dan menerima $\mathrm{Hl}$, yang berarati ukuran perusahaan (X1), umur perusahaan (X2), profitabilitas (X3), dan likuiditas (X4) secara bersama-sama berpengaruh positif signifikan terhadap pengungkapan ISR (Y). (Uji t)

Berikut hasil Uji hausman dapat dilihat pada tabel 4.7: 
Tabel 7.

Uji Signifikan Parsial (Uji †)

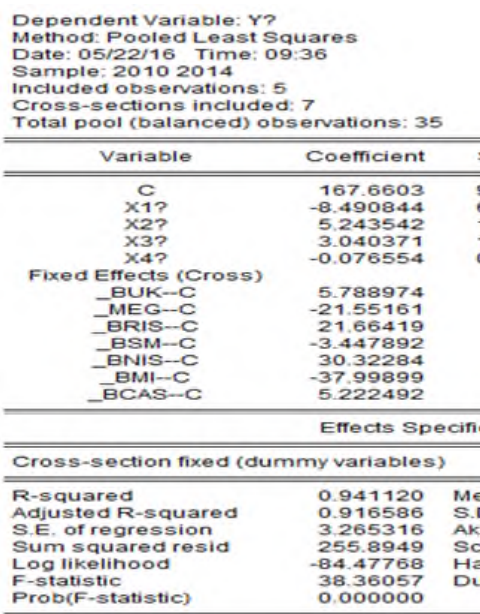

Sumber: Hasil penelitian, 2016 (diolah)

Hasil tabel 7 menunjukkan bahwa ukuran perusahaan (X1) yang diukur dengan total aset mempunyai nilai $t$ statistik sebesar - 1,293257, dengan nilai signifikan sebesar 0,2082 > taraf signifikan 0,05 . Hasil tersebut menunjukkan bahwa total aset berpengaruh negatif tidak signifikan terhadap pengungkapan ISR. Sedangkan variabel umur perusahaan (X2) mempunyai nilai † statistik sebesar 2,947625, dengan nilai signifikan sebesar $0,0070<$ taraf signifikan 0,05 . Hasil tersebut menunjukkan bahwa umur perusahaan berpengaruh positif signifikan terhadap pengungkapan ISR.

Variabel profitabilitas (X3) yang diukur dengan Return On Aset (ROA) mempunyai nilai $\dagger$ statistik sebesar 2,080570, dengan nilai signifikan sebesar $0,0483<$ taraf signifikan 0,05 . Hasil tersebut menunjukkan bahwa tingkat ROA berpengaruh positif signifikan terhadap pengungkapan ISR. Sedangkan variabel likuiditas (X4) yang diukur dengan Financing to deposite Ratio (FDR)

mempunyai nilai $\dagger$ statistik sebesar 0,668973, dengan nilai signifikan sebesar $0,5099>$ taraf signifikan 0,05 . Hasil tersebut menunjukkan bahwa tingkat FDR Protberpengaruh negatif tidak signifikan ,.2002

\section{Pembahasan}

Penjelasan untuk masing-masing hipotesis sebagai berikut:

\section{Secara simultan}

Pengaruh Ukuran Perusahaan, Umur Perusahaan, Profitabilitas, dan Likuiditas

\section{Terhadap Pengungkapan ISR}

Secara simultan menunjukkan ukuran perusahaan (X1) yang diukur dengan total aser, umur perusahaan (X2), profitabilitas (X3) yang diukur dengan ROA, dan likuiditas (X4) yang diukur dengan FDR secara bersama-sama berpengaruh positif signifikan terhadap pengungkapan ISR.

Sebagaimana penelitian yang dilakukan oleh Othman et.al (2009), Astuti (2013), Istiani (2015), Raditya (2012) dan Lestari (2016) yang menghasilkan secara simultan ukuran perusahaan, umur perusahaan profitabilitas, dan likuiditas, berpengaruh signifikan terhadap pengungkapan ISR.

Hal ini dikarenakan perusahaan yang lebih besar adalah perusahaan yang memiliki sumberdaya lebih banyak daripada perusahaan yang lebih kecil, perusahaan yang lebih besar sudah pasti memiliki pembiayaan, fasilitas, dan sumber daya manusia yang lebih banyak sehingga perusahaan besar melakukan pengungkapan ISR lebih luas (Othman 
et.al, 2009). Kemudian Lestari (2016)

beranggapan bahwa:

"Perusahaan yang lebih lama berdiri akan mendapatkan kepercayaan yang lebih dari para investor (pemilik modal) dan juga diketahui sangat mempengaruhi laporan tahunan perusahaan, karena memiliki informasi lebih banyak terkait dengan pengembangan dan pertumbuhan perusahaan tersebut".

Sedangkan untuk tingkat

profitabilitas, dinyatakan bahwa semakin besar tingkat laba yang diperoleh perusahaan maka pengelola akan memberikan lebih banyak motivasi untuk melakukan pengungkapan ISR yang lebih luas, sehingga mereka mendapatkan keuntungan dari profit tersebut (Othman et.al, 2009). Kemudian untuk kondisi perusahaan yang sehat, yang antara dapat ditunjukkan dengan tingkat likuiditas yang sesuai dengan batas aman yang ditentukan oleh Bank Indonesia, sehingga perusahaan yang sehat akan melakukan pengungkapan ISR lebih luas (Raditya, 2012). Jika dikaitkan dengan teori stakeholders dan Shariah Enterprise Theory (SET) maka bank syariah dapat dikatakan sudah memenuhi tanggungjawab dalam memenuhi informasi kinerja perusahaan baik secara bisnis (laporan keuangan) ataupun secara sosial (laporan sosial).

\section{Secara Parsial}

Pengaruh Ukuran Perusahaan Terhadap Pengungkapan ISR

Hasil Uji † menunjukkan bahwa total aset berpengaruh negatif tidak signifikan terhadap pengungkapan ISR. Artinya semakin besar ukuran perusahaan dalam hal ini bank syariah maka akan semakin sempit pengungkapan ISR yang dilakukan. Dengan demikian $\mathrm{Hl}$ dalam penelitian ini ditolak, dan menerima HO.

Hasil penelitian ini tidak sama dengan penelitian yang dilakukan oleh Othman et.al (2009), Rahajeng (2010), Raditya (2012), Putri (2014), Faricha (2015), Wulandari (2015), Istiani (2015), dan Permatasari (2015). Dimana hasil penelitian menunjukkan bahwa ukuran perusahaan berpengaruh signifikan terhadap pengungkapan ISR. Namun hasil penelitian ini sama dengan penelitian yang dilakukan Maulida, dkk (2014) dan Lestari (2016) yang menyatakan bahwa ukuran perusahaan yang diukur menggunakan total aset berpengaruh tidak signifikan terhadap pengungkapan ISR.

Jika dikaitkan dengan teori stakeholders dan Shariah Enterprinse Theory maka bank syariah dengan ukuran perusahaan yang diwakili oleh total aset yang tinggi belum tentu melakukan aktivitas sosial yang tinggi pula, sehingga terdapat hubungan yang tidak searah. Bank yang mempunyai ukuran perusahaan yang besar belum tentu banyak melakukan aktivitas sosial yang diungkapkan pada indeks ISR. Hal ini bisa terjadi karena total aset bukan menjadi satu-satunya tolak ukur untuk mengukur besar kecilnya suatu bank syariah, melainkan terdapat tolak ukur lain sepert modal saham, turnover, jumlah pemegang saham, aset lancar, aset 
tetap, pembiayaan stakeholders, dan bank borrowing.

\section{Pengaruh Umur Perusahaan Terhadap Pengungkapan ISR}

Hasil uji $\dagger$ menunjukkan bahwa umur perusahaan berpengaruh positif signifikan terhadap pengungkapan ISR. Artinya semakin besar umur perusahaan dalam hal ini bank syariah maka akan semakin luas pengungkapan ISR yang dilakukan. Dengan demikian HI dalam penelitian ini diterima, dan menolak HO.

Sebagaimana penelitian yang dilakukan oleh Lestari (2016) beranggapan bahwa:

"Perusahaan yang lebih lama berdiri akan mendapatkan kepercayaan yang lebih dari para investor (pemilik modal) dan juga diketahui sangat mempengaruhi laporan tahunan perusahaan, karena memiliki informasi lebih banyak terkait dengan pengembangan dan pertumbuhan perusahaan tersebut".

Hal ini juga didasarkan bahwa dengan memiliki umur yang lebih tua akan melakukan pengungkapan ISR lebih luas jika dibandingkan dengan perusahaan yang lebih muda, hal ini dikarenakan ketika perusahaan telah berdiri lebih lama akan lebih mengetahui keadaan perusahaan namun disisi lain tidak hanya mengetahui keadaan lingkungan perusahaan secara internal, namun juga akan lebih mengenal dan memahami keadaan lingkungan perusahaan secara ektsternal.

Sehingga jika dikaitkan dengan teori stakeholders dan Shariah Enterprise Theory maka perusahaan yang memiliki umur lebih tua akan lebih memahami kebutuhan dan tanggungjawabnya kepada Allah, stakeholders, dan alam mengenai laporan tahunan perusahaan. Adanya umur perusahaan yang semakin tua, maka wajar dalam hal ini bank syariah melakukan pengungkapan ISR yang lebih luas. Hal tersebut dikarenakan bank syariah sudah berpengalaman dalam hal melakukan aktivitas sosial.

\section{Pengaruh Profitabilitas Terhadap Pengungkapan ISR}

Hasil uji $†$ menunjukkan bahwa tingkat ROA berpengaruh positif signifikan terhadap pengungkapan ISR. Ini artinya bahwa semakin besar profitabilitas bank syariah maka akan semakin luas pengungkapan ISR yang dilakukan. Dengan demikian $\mathrm{H} 3$ dalam penelitian ini diterima dan $\mathrm{HO}$ ditolak.

Hasil penelitian ini sama dengan penelitian yang dilakukan oleh Othman et.al (2009), Rahajeng (2010), Raditya (2012), Maulida, dkk (2014), Kariza (2014), Wulandari (2015), dan Permatasari (2015) yang menjelaskan bahwa profitabilitas berpengaruh signifikan terhadap pengungkapan ISR, ini dikarenakan (Othman et.al, 2009):

"Semakin tinggi tingkat laba atau profit yang diperoleh bank syariah maka pengelola akan memberikan lebih banyak motivasi untuk melakukan pengungkapan ISR yang lebih luas, sehingga mereka mendapatkan keuntungan dari profit tersebut".

Pengaruh Likuiditas Terhadap

\section{Pengungkapan ISR}

Hasil uji $\dagger$ menunjukkan bahwa tingkat FDR berpengaruh negatif tidak 
signifikan terhadap pengungkapan ISR. Artinya semakin tinggi tingkat likuiditas bank syariah maka akan semakin sempit pengungkapan ISR yang dilakukan. Dengan demikian $\mathrm{H} 4$ dalam penelitian ini ditolak dan menerima $\mathrm{HO}$.

Hasil penelitian ini berbeda dengan penelitian yang dilakukan oleh Astuti (2013) yang menyatakan adanya pengaruh signifikan antara likuiditas dengan pengungkapan ISR. Namun penelitian ini sejalan dengan penelitian yang dilakukan oleh Istiani (2015) dan Lestari (2016) bahwa likuiditas tidak berpengaruh signifikan terhadap pengungkapan ISR. Hal tersebut dapat diartikan jika likuiditas tinggi maka pengungkapan ISR menurun sehingga terdapat hubungan yang tidak searah.

$$
\text { Menurut Bank Indonesia }
$$

menetapkan batas aman untuk rasio FDR yakni maksimal 110\% (Kasmir, 2010: 274). Dimana pada penelitian ini rata-rata rasio FDR sebesar $88,9 \%$, hal ini jika dikaitkan dengan ketentuan Bank Indonesia maka bank Syariah masih belum melaksanakan fungsi intermediasinya dengan baik. Besar kecilnya ukuran suatu likuiditas bank syariah jika dikaitkan dengan teori stakeholders dan Shariah Enterprise Theory maka seharusnya bank syariah tetap melakukan pengungkapan ISR dengan baik karena hal tersebut merupakan bagian dari tanggung jawab kepada Allah, stakeholders, dan alam.

\section{SIMPULAN}

Berdasarkan rumusan masalah, tujuan, landasan teori, hipotesis, hasil pengujian, analisis dan pembahasan, maka dapat ditarik kesimpulan sebagai berikut:

1. Secara simultan (Uji F), menunjukkan bahwa terdapat pengaruh signifikan antara ukuran perusahaan, umur perusahaan, profitabilitas, dan likuiditas terhadap pengungkapan ISR pada BUS di Indonesia tahun 20102014.

2. Secara parsial, variabel umur perusahaan dan profitabilitas berpengaruh signifikan terhadap pengungkapan ISR, sedangkan variabel ukuran perusahaan dan likuiditas berpengaruh tidak signifikan terhadap pengungkapan ISR pada BUS di Indonesia tahun 2010-2014.

Saran

Saran yang dapat disampaikan berdasarkan penelitian yang telah dilakukan adalah sebagai berikut:

1. Bagi Perbankan Syariah: Dengan adanya hasil penelitian diharapkan bank syariah lebih menjaga stabilitas likuiditas bank sesuai dengan ketentuan Otoritas Jasa Keuangan (OJK), karena dari hasil analisis menunjukkan bahwa masih terdapat nilai FDR terendah sebesar $68,93 \%$ yang menunjukkan belum sesuainya nilai dengan batas aman yang ditentukan oleh Bank Indonesia sebesar 110\%.

2. Penelitian selanjutnya: Disarankan untuk menambah variabel independen yang mungkin dapat 


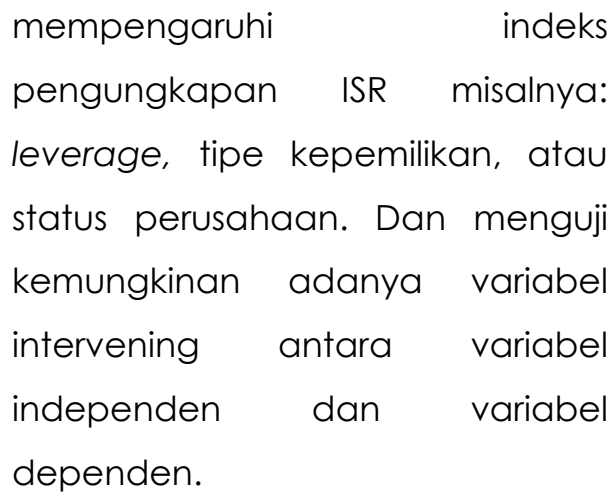

\section{DAFTAR PUSTAKA}

Ajija, Shocrul. dkk. 2011. Cara Cerdas Menguasai Eviews. Jakarta: Salemba Empat

Astuti, Tika. 2013. Pengaruh Profitabilitas, Likuiditas, dan Leverage Terhadap Pengungkapan Islamic Social Reporting (Studi Empiris pada Perusahaan yang Terdaftar di Jll tahun 2010-2012). Skripsi. Universitas Islam Negeri Syarif Hidayatullah Jakarta

Bank Indonesia. 2016. Jenis Bank Syariah di Indonesia tahun 2010-2015. http://www.Bl.com. Diakses Mei, 2016

Departemen Agama RI. 2010. Al-Qur'an Tajwid dan Terjemahan. Bandung: CV Diponegoro

Faricha, Nailil. 2015. analisis faktor-faktor yang mempengaruhi tingkat pengungkapan Islamic social reporting (ISR) pada perusahaan pertambangan yang terdaftar dalam Indek Saham Syariah Indonesia (ISSI) tahun 20112014. Skripsi. Universitas Negeri Surabaya

Fitria, Soraya dan Dwi Hartanti. 2010. Studi Perbandingan Pengungkapan Berdasarkan Global Reporting Initiative Index dan Islamic Social Reporting Index. Simposium Nasional Akuntansi XIII. Purwokerto.

Ghozali, Imam dan Dwi Rahmatmono. 2013. Analisis Multivariat dan Ekonometrika: teori, konsep, dan aplikasi dengan Eviews ${ }^{\circledR}$ 8. Semarang: BPFE Universitas Diponegoro

Haniffa. 2002. "Social Responsibility Disclosure: An Islamic Perspective". Indonesian Management and Accounting Journal, vol.1 no.2. Reference of publication

Haniffa, R dan Cooke. 2005. The Impact of Culture and Governance on Corporate
Social Reporting. Journal of Accounting and Public Policy, vol. 24. Pp 391-430

Istiani, Firda. 2015. Pengaruh Ukuran Bank, Profitabilitas, Likuiditas, dan Leverage Terhadap Pengungkapan Islamic Social Reporting (Studi Empiris Bank Umum syariah di Indonesia Tahun 2011-2014). Skripsi. UIN Syarif Hidayatullah

Kariza, Ayu. 2014. Faktor-Faktor yang Mempengaruhi Islamic social Reporting Perusahaan-Perusahaan yang Terdaftar pada Perusahaan yang Listing di Jakarta Islamic Index. Jurnal Akuntansi

Kasmir. 2010. Analisis Laporan Keuangan. Jakarta: Rajawali Press

Lestari, Santi. 2016. Pengaruh tingkat profitabilitas, likuiditas, leverage, ukuran perusahaan dan umur perusahaan terhadap indeks ISR pada perbankan syariah di Indonesia tahun 2010-2014. Jurnal Akuntansi Universitas Negeri Surabaya. Vol.4 No.2, pp.1-24

Maulida, Aldehita Purnasanti. dkk. 2014. Analisis Faktor-Faktor yang Mempengaruhi Pengungkapan Islamic Social Reporting (ISR). Skripsi. Universitas Negeri Semarang

Muhammad. 2015. Manajemen Dana Bank Syariah. Jakarta: PT Raja Grafindo

Othman, $\mathrm{R}$ et.al. 2009. Determinants Of Islamic Social Reporting Among Top Shariah-Approved Companies In Bursa Malaysia. Jurnal of International StudiesIssue

Othman, Rohana dan Azla Md Thani. 2010. Islamic Social Reporting Of Listed Companies In Malaysia. International Bussiness \& Economics Research, Vol.9 No.1, pp. 135-144

Permatasari, Vina Septiana. 2015. Pengaruh ukuran perusahaan, profitabilitas, dan ukuran dewan direksi terhadap indek islamic social reporting pada perusahaan yang terdaftar dalam jii tahun 2011-2013. Skripsi. Universitas Airlangga

Putri, Tria Karina. 2014. Faktor-Faktor yang Mempengaruhi Islamic social Reporting Perusahaan-Perusahaan yang Terdaftar pada Indeks Saham Syariah Indonesia (ISSI) Tahun 2011-2012. Skripsi. Universitas Diponegoro

Raditya, Amilia Nurul. 2012. Analisis faktorfaktor yang mempengaruhi tingkat pengungkapan Islamic social reporting 
(ISR) pada perusahaan yang masuk daftar efek syariah (DES). Skripsi. Universitas Indonesia

Rahajeng, Rahmi Galuh. 2010. FaktorFaktor yang Mempengaruhi Pengungkapan Sosial (Social Disclosure) Dalam Laporan Tahunan Perusahaan (Studi Empirirs Perusahaan Manufaktur di BEII. Skripsi. Universitas Diponegoro

Sembiring, Eddy R. 2003. Kinerja keuangan, political visibility, ketergantungan pada hutang, dan pengungkapan tanggungjawab perusahaan. Simposium Nasional Akuntansi VI

Sudana, I Made. 2011. Manajemen Keuangan Perusahaan Teori Dan Praktek. Jakarta: Erlangga

Triyuwono, Iwan. 2006. Perspektif, Metodelogi, dan Teori Akuntansi Syariah. Jakarta: PT. Raja Grafindo Persada.

Wibisono, Yusuf. 2007. Membedah konsep dan Aplikasi CSR Corporate Social Responbility. Gresik: Fascho Publishing

Wulandari, Fitri. 2015. Pengaruh Profitabilitas, ukuran perusahaan, kinerjaa lingkungan, dan leverage terhadap pengungkapan Islamic social reporitng (studi empiris pada perusahaan yang terdaftar di DES tahun 2014). Jurnal Akuntansi 